\title{
IgG Subclass Response to Immunization with Haemophilus influenzae Type b Polysaccharide-Outer Membrane Protein Conjugate Vaccine ${ }^{1}$
}

\author{
DAN M. GRANOFF, GEOFFREY A. WEINBERG, AND PENELOPE G. SHACKELFORD \\ Edward Mallinckrodt Department of Pediatrics, Washington University School of Medicine; and the Division of \\ Infectious Diseases, Children's Hospital, St. Louis, Missouri 63110
}

\begin{abstract}
We immunized 117 children with either $\mathrm{Hae}$ mophilus influenzae type b polysaccharide vaccine or type b polysaccharide coupled to an outer membrane protein of group B Neisseria meningitidis (conjugate vaccine), and measured the IgG, IgG1, and IgG2 subclass composition of antibody to type bolysaccharide in postimmunization sera by ELISA. The IgG responses of 51 children, 24-83 months of age, immunized for the first time with the conventional type b vaccine consisted of both IgG1 and IgG2 antibody (respective geometric means of $\mathbf{2 . 2 4}$ and $0.77 \mu \mathrm{g} / \mathrm{ml}$ ). In contrast, the IgG responses of 28 infants, 2-17 months of age, immunized with conjugate vaccine were predominantly or exclusively IgG1 (geometric mean IgG1 and IgG2 antibody concentrations of 1.92 and 0.19 $\mu \mathrm{g} / \mathrm{ml})$. A total of 38 children was primed with conjugate vaccine between 2 and 17 months of age and boosted approximately 1 yr later. The 28 children boosted with type b polysaccharide vaccine showed memory antibody responses consisting of both IgG1 and IgG2 (respective geometric means of 12.7 and $4.8 \mu \mathrm{g} / \mathrm{ml}$ ); the 10 children boosted with conjugate vaccine showed a similar pattern of IgG subclass responses (respective geometric means of 20.8 and $5.1 \mu \mathrm{g} / \mathrm{ml}, p>0.4$ compared to the respective geometric mean IgG1 and IgG2 values of the group boosted with polysaccharide). Thus, in children 24-83 months of age, immunization with conventional type b polysaccharide vaccine generally elicits both IgG1 and IgG 2 responses, with a slight predominance of IgG1. In contrast, in infants 2-17 months of age, immunization with conjugate vaccine evokes a restricted IgG1 antibody response to the polysaccharide but primes for both IgG1 and IgG2 responses to a booster immunization with conventional polysaccharide or conjugate vaccine. (Pediatr Res 24: 180-185, 1988)
\end{abstract}

Received December 10, 1987; accepted March 29, 1988

Reprint requests Dr. Dan Granoff at the Department of Pediatrics, Washington University School of Medicine, Division of Infectious Diseases, Children's Hospital, 400 South Kingshighway Blvd., St. Louis, MO 63110.

Supported by U.S. Public Health Service Grants RO1 AI17962 and AI19350, National Research Service Award F32 AI07559 from the National Institute of Allergy and Infectious Diseases, and Grant RR-36 from the General Clinical Research Center Branch, National Institutes of Health. G.A.W. is a recipient of the Burroughs Wellcome Fellowship in Infectious Diseases from the Infectious Diseases Society of America.

${ }^{1}$ Presented in part at the 26th Interscience Conference on Antimicrobial Agents and Chemotherapy, New Orleans, LA, October 1986, at the Annual Meeting of the Society for Pediatric Research, Anaheim, CA, May 1987, and at the Workshop on Clinical Aspects of IgG Subclasses and Therapeutic Implications, Interlaken, Switzerland, May 1987

\author{
Abbreviations \\ PS, polysaccharide \\ OMP, outer membrane protein \\ Hib, Haemophilus influenzae type b \\ ELISA, enzyme-linked immunosorbent assay \\ RABA, radioantigen binding assay
}

The factors affecting maturation of human antibody responses to PS antigens are poorly understood $(1,2)$. However, it is clear that the immunogenicity of a PS in infants can be greatly increased by covalently coupling the PS to a protein carrier $(2$, $3)$. In the resulting PS-protein conjugate, thymic-dependent features are conferred to the PS (4), and one observes boostable increases in serum antibody upon reinjection of the conjugate (4-7).

In recent years, the conjugate vaccine approach to immunization of infants with PS antigens has been applied most extensively to the development of a vaccine against Haemophilus influenzae type $\mathrm{b}$ (Hib) disease (3). This organism is the most common cause of bacterial meningitis in children in the United States. Several investigational Haemophilus type b conjugate vaccines have been prepared and tested in subjects of different ages (5-8). These conjugates are immunogenic in infants less than 12 months of age, a group characterized by very poor antibody responses to conventional Hib PS vaccine. Thus, detailed studies of the immune responses of humans of different ages to immunization with these unique conjugated antigens provide an opportunity to understand better the ontogeny of immune responses to PS antigens, especially in relation to the possible effects of the age of the host or the manner of presentation of the PS (i.e. T independent versus T dependent).

Several previous studies have examined the serum isotype responses of subjects immunized with different forms of Hib PS $(5,8-11)$. Children and adults immunized for the first time with either conventional Hib PS vaccine or one of the new Hib conjugate vaccines show both IgM and IgG responses. In addition, children primed in infancy with Hib PS-outer membrane protein conjugate vaccine and boosted 10-15 months later with either conventional Hib PS vaccine or with conjugate vaccine show evidence of a memory antibody response to the booster injection, and have substantial increases in IgG anti-Hib PS antibody (12). A similar memory antibody response to reimmunization recently was reported in children primed in infancy with an Hib oligosaccharide-protein conjugate vaccine (13). 
In humans and experimental animals, specific antibodies are not distributed randomly among the IgG subclasses (14). For example, in humans, IgG antibody responses to protein antigens are predominantly $\operatorname{IgG} 1(15,16)$ whereas $\operatorname{IgG}$ antibodies to polysaccharides such as streptococcal group A carbohydrate (17), dextran (18), or several pneumococcal capsular polysaccharides $(19,20)$ are predominantly $\operatorname{IgG} 2$. Until recently, the IgG responses to Hib PS were thought to be predominantly IgG2 (21). Further, the poor antibody responses of infants immunized with conventional Hib PS vaccine were thought, possibly to relate to delayed maturation of the ability of infants to produce antibodies of the $\operatorname{IgG} 2$ subclass. We recently found that immunization of adults with conventional $\mathrm{Hib}$ PS vaccine or Hib PS-diphtheria toxoid conjugate vaccine elicits substantial quantities of both IgG1 and IgG2 antibodies (22). These results have been confirmed in a study by Mäkelä et al. (23) in Finland. However, no comparable data are available on the subclass composition of $\mathrm{IgG}$ anti-Hib PS antibody in sera from immunized children. Such information is needed to understand better the immune mechanisms that infants and children are capable of mounting for protection against Hib disease.

The purposes of the present study were 2-fold: first, to compare the IgG1 and IgG2 subclass composition of serum anti-Hib PS antibody evoked by immunization of children with either conventional Hib PS vaccine, or with Hib PS coupled to a partially purified outer membrane protein of Neisseria meningitidis (Hib PS-OMP conjugate vaccine); and, second, to determine the subclass composition of IgG antibody elicited by a booster injection with either conventional Hib PS vaccine or Hib PS-OMP conjugate vaccine in children previously primed in infancy with conjugate vaccine.

\section{METHODS}

Subject selection. A total of 117 healthy children was vaccinated with conventional Hib PS vaccine or a conjugate of Hib PS coupled to a partially purified $N$. meningitidis OMP (24). Informed consent was obtained from one or both parents of the children. The protocol was approved by the Human Studies Committee of Washington University School of Medicine.

Group 1 consisted of 51 healthy white children who were vaccinated with $\mathrm{Hib}$ PS vaccine for the first time. The children ranged in age from 24 to 83 months (mean $\pm S D=47 \pm 17$ ). A total of 38 children were vaccinated with $5 \mu \mathrm{g}$ intramuscularly of vaccine prepared by P. Anderson, University of Rochester, Rochester, NY, a dose within the maximally immunogenic range $(25,26)$. The remaining 13 children received $25 \mu \mathrm{g}$ subcutaneously of Hib PS vaccine prepared by Praxis Biologics (Rochester, NY). There were no significant qualitative or quantitative differences in antibody responses of the children to the two vaccines and, therefore, the data from both groups were combined.

Group 2 consisted of 28 infants who were vaccinated for the first time with Hib PS-OMP conjugate vaccine. A single lot of vaccine was used (lot 1003/C-L680, Merck Sharp \& Dohme Research Laboratories, West Point, PA). Each dose, administered intramuscularly, contained $7 \mu \mathrm{g}$ of polysaccharide and $43 \mu \mathrm{g}$ of OMP. The 28 children in group 2 ranged in age from 2 to 17 months (mean $\pm \mathrm{SD}=7.8 \pm 4.9$ ). Twenty-seven were white and one was black. They were selected based upon availability of sufficient sera for testing from 63 vaccinated subjects described in a previous report (7).

Groups 3 and 4 consisted of 38 children previously vaccinated with two injections, separated by 1 month, of Hib PS-OMP conjugate vaccine (lot 1003/C-L680) at 2-17 months of age (mean $\pm \mathrm{SD}=6 \pm 4$ ). Ten to 15 months later, children in group $3(n=28)$ were boosted subcutaneously with $25 \mu \mathrm{g}$ of Hib PS vaccine (Praxis Biologics), and children in group $4(n=10)$ were boosted intramuscularly with Hib PS-OMP conjugate vaccine (lot 1018/C-M679, Merck Sharp \& Dohme Research Laborato- ries, West Point, PA). The dose of conjugate vaccine contained $7 \mu \mathrm{g}$ of PS and $23 \mu \mathrm{g}$ of outer membrane protein. A detailed description of the subjects in groups 3 and 4, the procedures of vaccination, and the IgG anti-Hib PS antibody responses have been reported (12).

Blood samples were obtained by venipuncture prior to immunization and 1-2 months after vaccination. Pre- and postimmunization samples were assayed for total anti-Hib PS antibody concentration by a RABA (25). Postimmunization sera were assayed for IgG, IgG1, and IgG2 anti-Hib PS antibody to ELISA as described below.

Serology. Serum IgG and IgG1 anti-Hib PS antibody concentrations were measured by ELISA as described $(22,25)$. In brief, Hib PS coupled to poly-1-lysine served as the antigen on the plate. Wells in a microtiter dish were incubated sequentially with test sera, biotin-conjugated secondary antibody specific for IgG or IgG1, avidin coupled to alkaline phosphatase, and $p$-nitrophenyl phosphate. Absorbance was monitored with a Titertek Multiscan spectrophotometer (Flow Laboratories, McLean, VA). Murine monoclonal antibody (HG11) specific for human IgG1 was used as the secondary antibody in the IgGl subclass assay. The specificity of this reagent has been described (27). The reagent used to detect $\mathrm{IgG}$ consisted of biotinylated heavy chainspecific goat antibody to human IgG purchased from Tago (Burlingame, CA). Serum IgG2 anti-Hib PS antibody was measured by ELISA as described $(22,25)$ except that a murine monoclonal antibody (HP 6014, ICN Immunology, Lisle, IL) was used rather than a polyclonal monkey antiserum. Inasmuch as the monoclonal was available as ascitic fluid, we used a biotinconjugated goat anti-mouse IgG (Tago) to detect binding of the monoclonal antibody. This goat antiserum had been absorbed to remove reactivity with human IgG.

Each class or subclass ELISA included known positive and negative control sera as well as serial 2-fold dilutions of the U.S. Office of Biologics (Bethesda, MD) H. influenzae type b human serum reference pool. A complete titration curve was generated for each test serum and the reference serum. The isotype specific antibody concentrations $(\mu \mathrm{g} / \mathrm{ml})$ of the test serum were assigned by comparison of the dilutions of test serum that produced an absorbance value of 0.6 with that of the U.S. Office of Biologics standard serum pool as described (22). In replicate assays performed on different days, the average difference in the respective IgG, IgG1, and IgG2 anti-Hib PS concentrations in individual test sera ranged from 12 to $18 \%(22)$.

Statistics. Analysis of antibody responses was performed on logarithmically transformed data. A Student's $t$ test (two-tailed) was used to compare the geometric mean concentrations of serum antibody among the groups. This method also was used to compare the geometric mean of the IgG1/IgG2 anti-Hib PS antibody ratios among the groups of subjects.

\section{RESULTS}

Table 1 summarizes the anti-Hib PS antibody responses of the infants and older children immunized for the first time with Hib PS-protein conjugate vaccine or conventional Hib PS vaccine, respectively. The total antibody data shown are from the radioantigen binding assay which measures all classes of immunoglobulin. As expected, before immunization, the children in group 1 who ranged in age from 24 to 83 months of age had higher serum antibody concentrations than the infants in group 2 who were 2 to 17 months of age (0.94 versus $0.17 \mu \mathrm{g} / \mathrm{ml}, p<0.001)$. After vaccination, subjects in both groups showed increases of approximately 10 -fold or more in the respective geometric means of the total antibody concentrations $(p<0.001$ for each group, comparing the respective geometric means of the values in pre- and postimmunization sera for each group). However, the geometric mean of the total antibody concentrations in the older children given conventional Hib PS vaccine was higher than that of the 
Table 1. Antibody responses of infants and children immunized for first time

\begin{tabular}{|c|c|c|c|c|c|}
\hline \multirow[b]{2}{*}{$\begin{array}{l}\text { Anticapsular } \\
\text { antibody }\end{array}$} & \multicolumn{2}{|c|}{$\begin{array}{c}\text { Group } 1 \\
\text { Hib PS vaccine }(n=51)^{*}\end{array}$} & \multicolumn{2}{|c|}{$\begin{array}{c}\text { Group 2 } \\
\text { Hib PS-OMP conjugate }(n=28) \dagger\end{array}$} & \multirow[b]{2}{*}{ Probability } \\
\hline & $\begin{array}{l}\text { Geo mean } \\
(\mu \mathrm{g} / \mathrm{ml})\end{array}$ & $\begin{array}{c}\text { Mean } \\
\left(\log _{10} \pm S D\right)\end{array}$ & $\begin{array}{l}\text { Geo mean } \\
(\mu \mathrm{g} / \mathrm{ml})\end{array}$ & $\begin{array}{c}\text { Mean } \\
\left(\log _{10} \pm \mathrm{SD}\right)\end{array}$ & \\
\hline \multicolumn{6}{|l|}{ Total } \\
\hline Pre & 0.94 & $-0.03 \pm 0.65$ & 0.17 & $-0.77 \pm 0.37$ & 0.001 \\
\hline Post & 8.05 & $0.91 \pm 0.73$ & 3.26 & $0.51 \pm 0.57$ & 0.02 \\
\hline \multicolumn{6}{|l|}{ Post } \\
\hline IgG & 3.64 & $0.56 \pm 0.68$ & 1.92 & $0.28 \pm 0.49$ & 0.06 \\
\hline IgG1 & 2.24 & $0.35 \pm 0.70$ & 1.24 & $0.09 \pm 0.53$ & 0.09 \\
\hline IgG2 & 0.77 & $-0.11 \pm 0.80$ & 0.19 & $-0.71 \pm 0.30$ & 0.001 \\
\hline
\end{tabular}

* Mean age $\pm \mathrm{SD}=47 \pm 17$ months.

$\dagger$ Mean age $\pm \mathrm{SD}=7.8 \pm 4.9$ months.

$\ddagger$ Student’s $t$ test comparing the respective geometric mean concentrations of subjects in group 1 with those of group 2 .

infants given the conjugate vaccine $(p<0.02)$. Also shown are the respective geometric means of the $\operatorname{IgG}, \operatorname{IgG} 1$, and $\mathrm{IgG} 2$ antiHib PS antibody concentrations in sera obtained 1 to 2 months after immunization. There was a trend for the older children vaccinated for the first time with conventional Hib PS vaccine to have higher geometric mean concentrations of IgG and IgG1 antibody than those of the infants given conjugate vaccine but the respective differences were not statistically significant $(p>$ 0.05 ). However, the geometric mean $\mathrm{IgG} 2$ antibody responses of the older children was significantly higher than that of the infants ( 0.77 versus $0.19 \mu \mathrm{g} / \mathrm{ml}, p<0.001$ ).

Figure 1 shows the individual ratios of IgG1 to IgG2 antibody in postimmunization sera from individual subjects immunized for the first time with Hib PS vaccine or Hib PS-OMP conjugate vaccine. In contrast to the data in Table 1, which include the results from all subjects in the appropriate groups, the data in Figure 1 are limited to the subjects considered to be IgG "responders" to vaccination. Responders were defined as those who had 2-fold or more increase in antibody after vaccination, and $\geq 1.9 \mu \mathrm{g} / \mathrm{ml}$ of IgG antibody in postimmunization sera. Individuals who did not meet this definition were excluded because of the high error in determining the ratios of subclass-specific antibody concentrations present in low titer sera. Twenty-six of the 51 children $(51 \%)$ vaccinated with conventional Hib PS vaccine, and 12 of the 28 infants $(43 \%)$ who received conjugate vaccine were considered to be IgG responders. The mean $\pm S D$ of the ages of the responders given PS vaccine was $51 \pm 17$ compared with $43 \pm 16$ in the nonresponders $(p<0.05$, onetail); the corresponding values for the group given conjugate vaccine was $9.8 \pm 4.8$ and $6.2 \pm 4.7$ months, respectively $(p<$ 0.05 , one-tail). There were no significant differences in the respective geometric means of the preimmunization total antibody concentrations of nonresponders and responders given conventional Hib PS vaccine or conjugate vaccine (data not shown) (IgG and IgG subclass determinations were not routinely performed in preimmune sera because of the low level of antibody present). As shown in Figure 1, the IgG antibody responses of most subjects immunized with PS vaccine were predominantly IgG1 (IgG1/IgG2>1), although five of the 26 responder children (19\%) had predominantly $\operatorname{IgG} 2$ responses $(\operatorname{IgG} 1 / \operatorname{IgG} 2<1)$. In contrast, all $12 \mathrm{IgG}$ responders given conjugate vaccine had predominantly or exclusively $\operatorname{IgG} 1$ responses. The geometric mean ratio of $\mathrm{IgG} 1$ to $\mathrm{IgG} 2$ in the responders given conventional Hib PS vaccine was 2.8 compared with 14.9 in the responders given conjugate vaccine $(p<0.001)$.

Table 2 summarizes the respective antibody responses to booster immunization with conventional $\mathrm{Hib}$ PS vaccine or Hib PS-OMP conjugate vaccine in children previously primed with conjugate vaccine. This analysis includes data from all subjects who received a booster injection, irrespective of their responder/ nonresponder status (see below). The children were boosted at

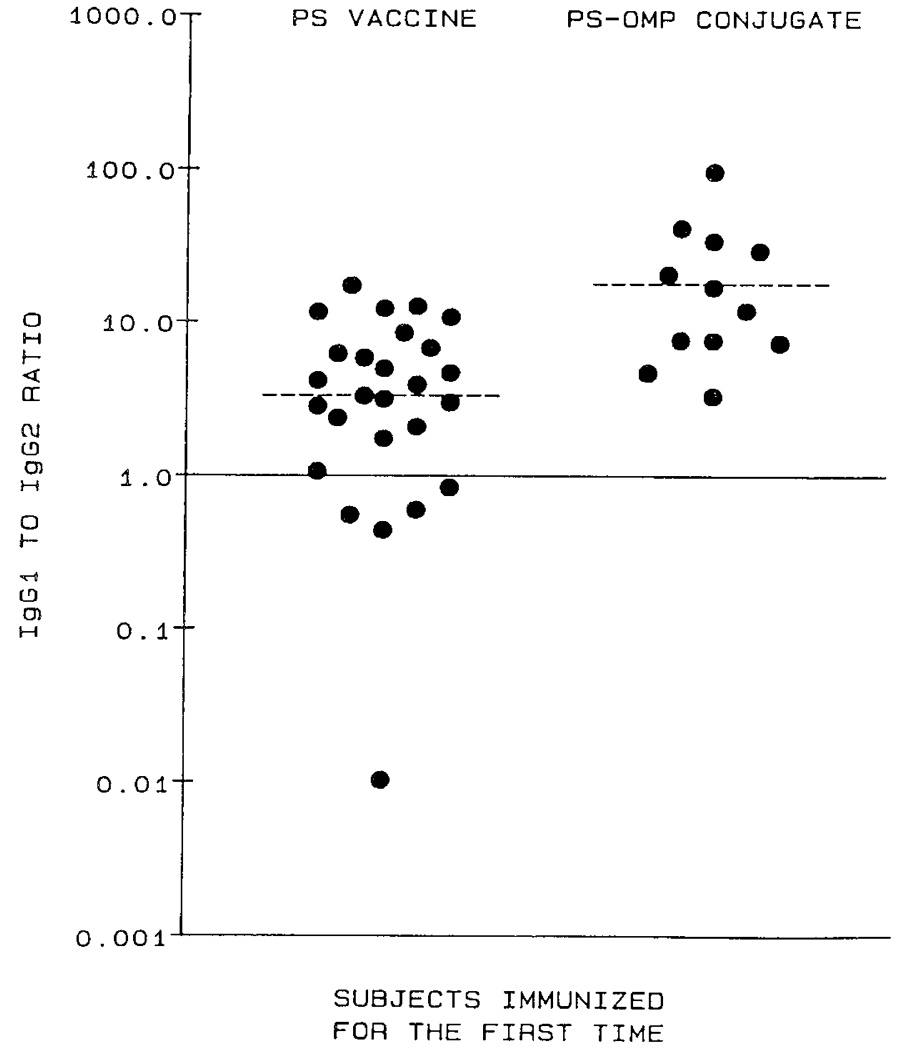

Fig. 1. Subclass composition of serum anti-Hib PS antibody response of children 24-83 months of age vaccinated for the first time with Hib PS vaccine (group 1, left), or infants 2-17 months of age vaccinated for the first time with Hib PS-OMP conjugate vaccine (group 2, right). Each point represents the ratio of IgG1 to IgG2 anti-Hib PS antibody in an individual $\mathrm{IgG}$ responder to vaccine (see text for definition of responder). The bars represent the geometric means of the ratios for each group.

14 to 31 months of age, which was 10 to 15 months after their last injection with conjugate vaccine (12). The mean age of the group boosted with Hib PS vaccine was 19.9 months and that of the group boosted with conjugate vaccine was 18.8 months $(p>$ 0.5 ). There were no significant differences in the respective geometric means of the total, IgG, IgG1, and IgG2 Hib PS antibody concentrations in the sera from the two groups. Both groups showed predominantly IgG1 responses although in the postimmune sera there also were substantial concentrations of IgG2 antibody evoked by the booster injections.

Figure 2 shows the ratios of $\mathrm{IgG} 1$ to $\mathrm{IgG} 2$ antibody of the individual subjects given booster immunizations. As was the case 
Table 2. Antibody responses to booster injection in children previously primed with conjugate vaccine*

\begin{tabular}{|c|c|c|c|c|}
\hline \multirow[b]{3}{*}{$\begin{array}{l}\text { Anticapsular } \\
\text { antibody }\end{array}$} & \multicolumn{4}{|c|}{ Booster vaccine } \\
\hline & \multicolumn{2}{|c|}{$\begin{array}{c}\text { Group } 3 \\
\text { Hib PS vaccine } \\
\quad(n=28) \dagger\end{array}$} & \multicolumn{2}{|c|}{$\begin{array}{c}\text { Group } 4 \\
\text { Hib PS-OMP conjugate } \\
(n=10) \ddagger\end{array}$} \\
\hline & $\begin{array}{c}\text { Geo mean } \\
(\mu \mathrm{g} / \mathrm{ml})\end{array}$ & $\begin{array}{c}\text { Mean } \\
\left(\log _{10} \pm S D\right)\end{array}$ & $\begin{array}{l}\text { Geo mean } \\
(\mu \mathrm{g} / \mathrm{ml})\end{array}$ & $\begin{array}{c}\text { Mean } \\
\left(\log _{10} \pm S D\right)\end{array}$ \\
\hline \multicolumn{5}{|c|}{ Total } \\
\hline Pre & 0.7 & $-0.14 \pm 0.71$ & 1.0 & $-0.01 \pm 0.63$ \\
\hline Post & 33.1 & $1.52 \pm 0.57$ & 41.7 & $1.62 \pm 0.36$ \\
\hline \multicolumn{5}{|l|}{ Post } \\
\hline $\lg G$ & 16.2 & $1.21 \pm 0.66$ & 18.2 & $1.26 \pm 0.41$ \\
\hline $\mathrm{IgGl}$ & 12.7 & $1.10 \pm 0.79$ & 20.8 & $1.32 \pm 0.54$ \\
\hline $\operatorname{IgG} 2$ & 4.8 & $0.68 \pm 0.91$ & 5.1 & $0.71 \pm 0.53$ \\
\hline
\end{tabular}

* There were no significant differences between the respective geometric mean antibody concentrations of subjects in group 3 and those of subjects in group 4 ( $p>0.4$ by $t$ test).

$\dagger$ Mean age at booster $\pm \mathrm{SD}=19.9 \pm 4.4$ months

$\ddagger$ Mean age at booster $\pm \mathrm{SD}=18.8 \pm 5.3$ months.

with the data presented in Figure 1, the data shown in Figure 2 represent the individual ratios of the "responders" only. However, in the latter instance, 26 of the 28 subjects boosted with conventional Hib PS vaccine $(93 \%)$ and all 10 subjects boosted with conjugate vaccine were considered $\mathrm{IgG}$ responders. A total of 22 of the 26 responders boosted with conventional Hib PS vaccine and seven of the 10 children boosted with conjugate vaccine showed predominantly IgG1 responses (ratios $>1.0$ ). There was no significant difference in the geometric means of the IgG1 to IgG2 antibody ratios of the children in the two groups of (2.6 versus $4.2, p=0.29)$. The geometric means of the ratios also did not differ significantly from the geometric mean $\mathrm{IgG} 1 / \mathrm{IgG} 2$ ratio of the children 24 to 83 months of age in group 1 given conventional Hib PS vaccine for the first time (geometric mean $=2.8$ )

\section{DISCUSSION}

Recent reports indicate that the $\mathrm{IgG}$ antibody responses to some PS antigens are not restricted to IgG2, and that most adults vaccinated with $\mathrm{Hib}$ or meningococcal group A PS develop substantial amounts of $\operatorname{IgG} 1$ as well as $\operatorname{IgG} 2$ antibody $(22,23$, $28,29)$. Our results extend the data on anti-Hib PS IgG subclass responses to measurement of the $\mathrm{IgG} 1$ and $\mathrm{IgG} 2$ responses of children and infants vaccinated with conventional Hib PS vaccine or a Hib-PS protein conjugate vaccine containing an outer membrane protein as the carrier. Because of previous data on the lack of immunogenicity of the Hib PS vaccine in infants (2, 3 ), we only immunized the infants in this study with conjugate vaccine. The data indicate that infants $<18$ months of age given conjugate vaccine show IgG responses that are highly restricted to IgG1 (Fig. 1). In contrast, children 24 to 83 months of age immunized. with conventional Hib PS vaccine have both IgG1 and $\operatorname{IgG} 2$ antibody responses with a predominance of IgG1 (IgG1/IgG2 $>1$, Fig. 1). The restricted IgG1 antibody responses of the infants given the conjugate vaccine are similar to those observed previously in patients 24 to 59 months of age recovering from invasive $\mathrm{Hib}$ disease (30). Further investigation will be required to determine the potential importance of the differences in IgG subclass distribution of anticapsular antibody in protection against disease (31).

It is not clear why the infants in this study immunized for the first time with conjugate vaccine produced predominantly or exclusively IgG1 responses. One possible explanation is that IgG1

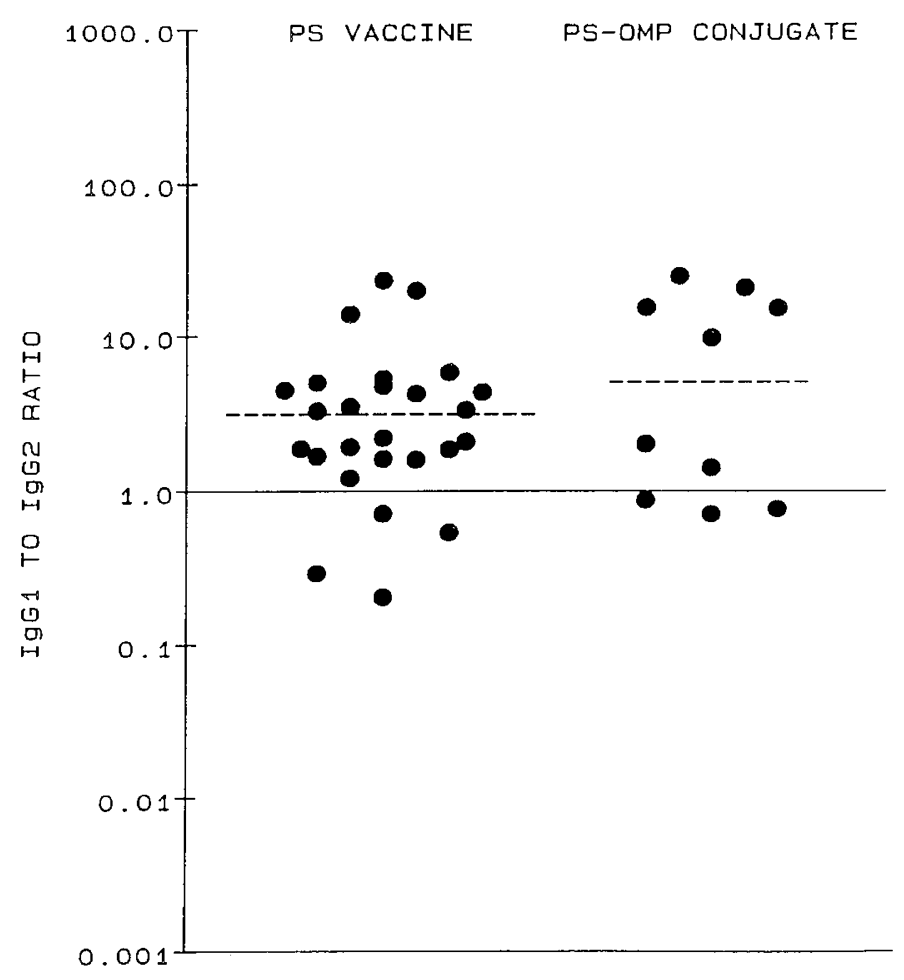

CHILDREN PREVIOUSLY PRIMED WITH PS-OMP VACCINE

Fig. 2. Subclass composition of serum anti-Hib PS antibody booster responses of children previously primed in infancy with Hib PS-OMP conjugate vaccine. Subjects in group $3(l e f t)$ were revaccinated at a mean age of 19.9 months with conventional Hib PS vaccine, and subjects in group 4 (right) were revaccinated at a mean age of 18.8 months with conjugate vaccine. In each group, reimmunization occurred 10-15 months after the last dose of conjugate. Each point represents the ratio of IgG1 to IgG2 anti-Hib PS antibody in an individual IgG responder to vaccine (see text for definition of responder). The geometric mean ratios, represented by the bars, were not significantly different for each group.

may be the predominant subclass induced by immunization with $\mathrm{T}$-dependent antigens, whereas $\mathrm{T}$-independent antigens may evoke predominantly IgG2 responses (23). Consistent with this explanation is our recent finding of a predominance of IgG1 antibody responses in sera from 17 children, 24-60 months of age, vaccinated for the first time with Hib PS-OMP conjugate vaccine (geometric mean IgG1 and IgG2 antibody concentrations of 4.47 and $0.72 \mu \mathrm{g} / \mathrm{ml}$; sera kindly provided by Dr. Phillip Vella, Merck, Sharp \& Dohme). The hypothesis that T-dependent antigens evoke higher IgG1 responses than T-independent forms of the antigen does not explain previous data indicating that adults given conventional Hib PS vaccine ( $\mathrm{T}$ independent) or Hib PS-diphtheria toxoid conjugate vaccine (presumably, T dependent) show relatively similar proportions of $\mathrm{IgG} 1$ and $\mathrm{IgG} 2$ anti-Hib PS antibody $(22,23)$. In addition, six adults immunized previously with the same Hib PS-OMP conjugate vaccine as used in the infants in the present study showed substantial increases in both $\mathrm{IgG} 1$ and $\mathrm{IgG} 2$ antibody (geometric mean ratio of $\mathrm{IgG} 1$ to IgG2 in postimmunization sera of 1.1 , data not shown). It is likely that most of the adults vaccinated in these studies had been exposed previously to type b Haemophilus or to enteric bacteria containing polysaccharide antigens cross-reactive with the type $b$ polysaccharide. In contrast, the majority of the immunized infants and older children may not have been exposed previously (or, if previously exposed, not to a form of the antigen suitable for priming in this age group). Conceivably, in unprimed individuals, the conjugate vaccine primarily evokes IgG1 re- 
sponses, whereas primed individuals show both $\operatorname{IgG} 1$ and $\operatorname{IgG} 2$ responses. Whether the predominance of $\operatorname{IgG} 1$ responses of the infants and older children to the primary immunization with the conjugate reflects lack of activation of $B$ cell subsets specific for $\mathrm{IgG} 2$ or lack of isotype switching to IgG2 by the activated B cells cannot be distinguished by the present data $(14,32)$.

Not all infants $<18$ months of age vaccinated with conjugate vaccine develop serum antibody levels $>1 \mu \mathrm{g} / \mathrm{ml}$ (5-7). However, previous studies have shown that children primed in infancy with conjugate vaccine have $\mathrm{IgG}$ memory antibody responses to a subsequent booster injection with either conventional Hib PS vaccine $(12,13)$ or conjugate vaccine $(12)$, and this memorytype response is observed even in children who show meager antibody responses to the primary immunization. The magnitude of the total IgG responses of the primed children to reimmunization with the polysaccharide vaccine is comparable to that of adults immunized for the first time with conventional Hib PS vaccine $(12,13)$.

Our study provides data on the IgG subclass composition of the booster responses of children primed in infancy with the Hib PS-OMP conjugate vaccine. As summarized in Table 2 and Figure 2, most subjects boosted with either conventional Hib PS vaccine or conjugate vaccine showed a predominance of $\mathrm{IgG} 1$ antibody (IgG1/IgG2 $>1.0)$. This result is consistent with increased expression of $\mathrm{B}$ cell clones previously stimulated by the primary immunization with the conjugate. However, after the booster immunization, nearly all of the subjects also showed substantial increases in their serum concentrations of IgG2 antibody, and seven of the 36 subjects showed a predominance of IgG2 antibody to the booster injection (IgG1 to IgG2 ratio $<1$, Fig. 2). Note that the geometric mean IgG2 antibody concentration after the booster injection with the PS vaccine is substantially higher than that observed in children, 24-to 83 months of age, immunized for the first time with conventional Hib PS vaccine (4.8 versus $0.77 \mu \mathrm{g} / \mathrm{ml}, p<0.001$; compare Table 2 to Table 1 ). Similarly, the $\operatorname{IgG} 1$ responses to the booster injection with $\mathrm{Hib}$ polysaccharide vaccine are higher than primary vaccination with polysaccharide, even when given at an older age (geometric means of 12.7 versus $2.24 \mu \mathrm{g} / \mathrm{ml}, p<0.001$ ). Therefore, although primary immunization of infants with conjugate vaccine evokes a restricted IgG1 antibody response, it primes for both IgG1 and IgG2 booster responses to a subsequent injection with conventional Hib PS vaccine or Hib PS-OMP conjugate vaccine (Table 2). Although not examined directly, the IgG2 responses of the children to the booster injection could result from stimulation of new B cell clones or activation of a subclass switch from IgG1 to IgG2. To date, the only available data addressing this question are those of Insel and Anderson (32). They analyzed the clonal diversity of IgG antibody induced by immunization of infants with an Hib oligosaccharide-protein conjugate vaccine, followed by boosting with Hib PS vaccine. In most subjects, reimmunization with the Hib PS vaccine increased expression of clones previously stimulated by the conjugate. However, occasionally new clonotypes were observed (32).

As noted above, the IgG anticapsular antibody response of adults immunized with Hib PS vaccine or Hib PS-protein conjugate vaccines is heterogeneous and is composed mainly of IgG1 and IgG2 $(22,23)$. Mäkelä et al. (23) recently reported that a few immunized adults also showed a small IgG3 component $(<6 \%$ of IgG) and, rarely, an IgG4 component ( $<1 \%$ of IgG). Comparable data are not available from children. It is possible, therefore, that immunized children may also occasionally respond with IgG3 or IgG4 antibody. Attempts are currently underway in our laboratory to develop a quantitative IgG3 and IgG4 anti-Hib PS ELISA to examine this question.

Acknowledgments. Drs. Menachem Einhorn, Paul Granoff, and Eyla Boies vaccinated the subjects and collected the sera used in this study. Katherine Sheetz, Kathleen Lottenbach, and Venita Boelloeni provided expert technical assistance. Frances
LoCascio typed the manuscript. Drs. K. Lynn Cates and Moon Nahm reviewed the manuscript.

\section{REFERENCES}

1. Mosier DE, Subbarao B 1982 Thymus-independent antigens: complexity of Blymphocyte activation revealed. Immunol Today 3:217-222

2. Robbins JB 1978 Vaccines for the prevention of encapsulated bacterial diseases: current status, problems and prospects for the future. Immunochemistry 15:839-854

3. Granoff DM, Munson RS Jr 1986 Prospects for prevention of Haemophilus influenzae type $\mathrm{b}$ disease by immunization. $\mathrm{J}$ Infect Dis 153:448-461

4. Schneerson R, Barrera O, Sutton A, Robbins JB 1980 Preparation, characterization and immunogenicity of Haemophilus influenzae type b polysaccharide-protein conjugates. J Exp Med 152:361-376

5. Lepow ML, Samuelson JS, Gordon LK 1985 Safety and immunogenicity of Haemophilus influenzae type b-polysaccharide diphtheria toxoid conjugate vaccine in infants 9 to 15 months of age. J Pediatr 106:185-189

6. Anderson PW, Pichichero ME, Insel RA, Betts R, Eby R, Smith DH 1986 Vaccines consisting of periodate-cleaved oligosaccharides from the capsule of Haemophilus influenzae type b coupled to a protein carrier: structural and temporal requirements for priming in the human infant. $J$ Immunol 137:1181-1186

7. Einhorn MS, Weinberg GA, Anderson EL, Granoff PD, Granoff DM 1986 Immunogenicity in infants of Haemophilus influenzae type b polysaccharide in a conjugate vaccine with Neisseria meningitidis outer-membrane protein. Lancet 2:299-302

8. Schneerson R, Robbins JB, Parke JC Jr, Bell C, Schlesselman JJ, Sutton A Wang Z, Schiffman G, Karpas A, Shiloach J 1986 Quantitative and qualitative analysis of serum antibodies elicited in adults by Haemophilus influenzae type $\mathrm{b}$ and pneumococcus type $6 \mathrm{~A}$ capsular polysaccharide-tetanus toxoid conjugates. Infect Immun 52:519-528

9. Insel RA, Anderson P, Pichichero ME, Amstey MS, Ekborg G, Smith DH 1982 Anticapsular antibody to Haemophilus influenzae type b. In: Sell SH Wright PF (eds) Haemophilus influenzae: Epidemiology, Immunology and Prevention of Disease. Elsevier Science Publishing Co., New York, pp. 155168

10. Granoff DM, Boies EG, Munson RS Jr 1984 Immunogenicity of Haemophilus influenzae type $\mathrm{b}$ polysaccharide-diphtheria toxoid conjugate vaccine in adults. J Pediatr 105:22-27

11. Käyhty H, Schneerson R, Sutton A 1982 Class-specific antibody response to Haemophilus influenzae type b capsular polysaccharide vaccine. J Infect Dis 148:767

12. Weinberg GA, Einhorn MS, Lenoir AA, Granoff PD, Granoff DM 1987 Immunologic priming to capsular polysaccharide in infants immunized with Haemophilus influenzae type b polysaccharide-Neisseria meningitidis outer membrane protein conjugate vaccine. J Pediatr 111:22-27

13. Anderson P, Pichichero M, Edwards K, Porch CR, Insel R 1987 Priming and induction of Haemophilus influenzae type $\mathrm{b}$ capsular antibodies in early infancy by Dpo 20 , an oligosaccharide-protein conjugate vaccine. $J$ Pediat 111:644-650

14. Nahm MH, Scott MG, Shackelford PG 1987 Expression of human IgG subclasses. Ann Clin Lab Sci 17:183-196

15. Stevens R, Dichek D, Keld B, Heiner D $1983 \mathrm{IgG} 1$ is the predominant subclass of in vivo and in vitro produced anti-tetanus toxoid antibodies and also serves as the membrane $\operatorname{IgG}$ molecule for delivering inhibitory signals to antitetanus toxoid antibody-producing B cells. J Clin Immunol 3:65-69

16. Seppälä IJT, Rautonen N, Sarnesto A, Mattila PS, Mäkelä O 1984 The percentages of six immunoglobulin isotypes in human antibodies to tetanus toxoid: standardization of isotype-specific second antibodies in solid-phase assay. Eur J Immunol 14:868-875

17. Riesen WF, Skvaril F, Braun DG 1976 Natural infection of man with group A streptococci. Levels; restriction in class, subclass, and type; and clonal appearance of polysaccharide group-specific antibodies. Scand J Immunol $5: 383-390$

18. Yount WJ, Dorner MM, Kunkel HG, Kabat EA 1968 Studies on human antibodies. VI. Selective variations in subgroup composition and genetic markers. J Exp Med 127:633-648

19. Freijd A, Hammarstrom L, Persson MAA, Smith CIE 1984 Plasma antipneumococcal antibody activity of the $\mathrm{IgG}$ class and subclass in otitis prone children. Clin Exp Immunol 56:233-238

20. Barrett DJ, Ayoub EM $1986 \mathrm{IgG} 2$ subclass restriction of antibody to pneumococcal polysaccharides. Clin Exp Immunol 63:127-134

21. Johnston RB Jr, Anderson P, Rosen FS, Smith DH 1973 Characterization of human antibody to polyribophosphate, the capsular antigen of Haemophilus influenzae, type b. Clin Immunol Immunopathol 1:234-240

22. Shackelford PG, Granoff DM, Nelson SJ, Scott MG, Smith DS, Nahm MH 1987 Subclass distribution of human antibodies to Haemophilus influenzae type b capsular polysaccharide. J Immunol 138:587-592

23. Mäkelä O, Matilla P, Rautonen N, Seppälä I, Eskola J, Käyhty H 1987 Isotype concentrations of human antibodies to Haemophilus influenzae type b polysaccharide (Hib) in young adults immunized with the polysaccharide as such or conjugated to a protein (diphtheria toxoid). J Immunol 139:19992004

24. Marburg S, Jorn D, Tolman RL, Arison B, McCauley J, Kniskern PJ, Hagopian A, Vella PP 1986 Bimolecular chemistry of macromolecules: synthesis of bacterial polysaccharide conjugates with Neisseria meningitidis membrane 
protein. J Am Chem Soc 108:5282-5287

25. Granoff DM, Shackelford PG, Pandey JP, Boies EG 1986 Antibody responses to Haemophilus influenzae type b polysaccharide vaccine in relation to the $\mathrm{Km}(1)$ and $\mathrm{G} 2 \mathrm{~m}(23)$ immunoglobulin allotypes. J Infect Dis 154:257-264

26. Smith DH, Peter G, Ingram DL, Harding AL, Anderson P 1973 Responses of children immunized with the capsular polysaccharide of Haemophilus influenzae type b. Pediatrics 52:637-644

27. Scott MG, Nahm MH 1984 Mitogen induced human IgG subclass expression. J Immunol 133:2454-2460

28. Rautonen N, Pelkonen J, Sipinen S, Käyhty H, Mäkelä O 1986 Isotype concentrations of human antibodies to Group A meningococcal polysaccharide. J Immunol 137:2670-2675

29. Granoff DM, Suarez BK, Pandey JP, Shackelford PG 1988 Genes associated with the $\mathrm{G} 2 \mathrm{~m}(23)$ immunoglobulin allotype regulate the IgG subclass responses to Haemophilus influenzae type b polysaccharide vaccine. $\mathrm{J}$ Infect Dis $157: 1142-1149$

30. Granoff DM, Shackelford PG $1987 \mathrm{IgG}$ responses to $H$. influenzae type b (Hib) and pneumococcal types 3 and 23 polysaccharides (PS) in children developing Hib disease despite vaccination with $\mathrm{Hib}$ PS vaccine. Pediatr Res $21: 325 \mathrm{~A}$

31. Weinberg GA, Granoff DM, Nahm MH, Shackelford PG 1986 Functional activity of different IgG subclass antibodies against type $b$ capsular polysaccharide of Haemophilus influenzae. J Immunol 136:4232-4236

32. Insel RA, Anderson PW 1986 Oligosaccharide-protein conjugate vaccines induce and prime for oligoclonal $\mathrm{IgG}$ antibody responses in human infants. J Exp Med 163:262-269 